\title{
GC-MS Analysis of Young Leaves of Allophylus cobbe (L.) Raeusch. and Allophylus serratus (Roxb.) Kurz.
}

\author{
Chavan Reshama Bharat and Gaikwad Dattatraya Krishna \\ Department of Botany, Shivaji University, Vidyanagar, Kolhapur, 416004, (MS) INDIA.
}

\begin{abstract}
Background: Allophylus cobbe(L.) Raeusch. and Allophylus serratus (Roxb.)Kurz. (Sapindaceae) are medicinal plants traditionally used to cure bone fractures and other ailments in India. Objective: Present work was aimed at the identification of phytochemical compounds from young leaves of $A$. cobbe and $A$. serratus by applying gas chromatography mass spectrometry. Method: GC-MS technique was used for analysis of compounds. Results: It indicates 11 compounds from $A$. serratus and seven compounds from $A$. cobbe having mixture of terpenoids, alkanes and fatty acids. The major compounds found in $A$. cobbe were 1,1-diethoxy ethane (82.97\%) (RT: $3.192 \mathrm{~min}$ ), phytol (7.07\%) (RT: $43.690 \mathrm{~min})$ and hexanoic acid (3.67\%) (RT: $29.576 \mathrm{~min}$ ) while in $A$. serratus 3-methyl butanol (53.16\%) (RT: $3.223 \mathrm{~min}$ ), 2-propenoic acid, 2-(dimethylamino) ethyl ester $(27.08 \%)$ (RT: $13.94 \mathrm{~min}$ ) and diisocytyl phthalate (4.49\%) (RT: $52.584 \mathrm{~min}$ ) were found in higher quantity. Phytol was detected from both species. Phytol possesses anti-radical, anti-cancer, antibacterial and anti-inflammatory properties as well as used in artificial synthesis of vitamin $\mathrm{E}$ and vitamin $\mathrm{K}$ in cosmetics and fragrance industry. Conclusion: The abundant presence of phytol in leaves of Allophylus species $17.07 \%$ in A. cobbe and $2.60 \%$ in $A$. serratus) suggests that these species may prove helpful in prevention of degenerative diseases and application of these herbs in cosmetics which may prove a cost effective natural alternative to current synthetic cosmetics. Presence of industrially important chemicals like phytol, 1,1-diethoxy ethane, hexanoic acid, diisocytyl phthalate, 2-propeonic acid, 2-(dimethylamino) ethyl ester underlines industrial importance of these species which needs further research on this aspect to focus in detail.
\end{abstract}

Key words: GC-MS Analysis, Allophylus Cobbe, Allophylus Serratus, Young Leaves, phytol, medicinal plants.

\section{INTRODUCTION}

Allophylus (family Sapindaceae) having about 255 species found worldwide out of which nine species are found in India. ${ }^{1} A$. cobbe and A. serratus are species found in Maharashtra state of India. ${ }^{2}$ These two species are found in various localities of Kolhapur district of Maharashtra State. ${ }^{3}$ Most of the local people in Maharashtra call both the species by a same name- Tipan (in Marathi language). ${ }^{4}$ The fresh leaves of these species are tied over the bone fractures for a faster recovery. ${ }^{4}$ The fresh leaves as well as dry powder of leaves are also taken with small amount of jaggery at early morning with empty stomach, for relief from joint pains. ${ }^{4}$ Leaves of $A$. cobbe are used by local people against bone fractures, ${ }^{5}$ rashes, ${ }^{6}$ and stomach ache. ${ }^{6}$ Benzylamide is isolated from leaves of A. cobbe (L.) Raeusch ${ }^{7}$. A. serratus is used against bone fractures. ${ }^{8}$ A. serratus (Kurz) leaves contain $\beta$-sitostrerol ${ }^{9}$ and phenacetamide, an anti-ulcer phytochemical. ${ }^{10}$ Kumar et al. observed osteogenic activity of rutin isolated from stem of $A$. serratus in in vitro studies. ${ }^{11}$ Chavan and Gaikwad reported antibacterial activity of $A$. serratus and $A$. cobbe. ${ }^{12}$

In recent years, GCMS is being a helpful tool to identify the phytochemicals from the medicinal plants and various natural products; because it is a non-destructive, direct and fast analytical method
Submission Date: 08-12-2016; Revision Date: 24-01-2017; Accepted Date: 18-03-2017

DOI: 10.5530/ijper.51.3.75 Correspondence: Dr. Chavan Reshama Bharat, (M.Sc. Ph.D. Botany) Department of Botany, Shivaji University, Kolhapur 416 004, INDIA. Phone no: 8722793734 E mail: c-reshma@mail.com

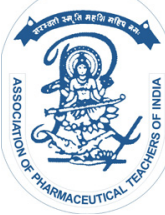

www.ijper.org 
for identification of terpenoids, fatty acids and other phytochemicals as well as a very less plant material is required.

The phytochemical information of young leaves of these species is scanty. Hence, present investigation was aimed at characterizing chemical components of these species.

\section{MATERIAL AND METHODS}

\section{Collection of plant material}

Young leaves of $A$. cobbe and $A$. serratus were collected from forest of Panhala (Kolhapur district, Maharashtra State, India). The material was washed with water, blotted to dry and kept in oven at $60^{\circ} \mathrm{C}$ until gaining the constant weight. The completely dried material was taken out, finely ground with Willey's grinding machine and these powders were kept in airtight containers until use.

\section{Extraction of Plant Material}

$5 \mathrm{~g}$ of dry powders of young leaves of $A$. serratus and A. cobbe were taken and extracted at $60^{\circ} \mathrm{C}$ in absolute ethanol (Merck) up to $8 \mathrm{hr}$ by using soxhlet apparatus. After completion of extraction, extract was taken out, poured in evaporating dish, kept on water bath $\left(60^{\circ} \mathrm{C}\right)$ and evaporated to dryness. Resulting residue remained at bottom of evaporating dish was dissolved in $5 \mathrm{ml}$ absolute ethanol and used for GC-MS analysis.

\section{Chromatographic analysis}

GC-MS analysis was performed on a Shimadzu (Tokyo, Japan) Make QP-2010 with nonpolar 60 M RTX 5MS capillary column, full scan mode, injector mode-split, (split ratio 1:20), quadra pole mass selective detector (MSD), injection temperature $220^{\circ} \mathrm{C}$, GC-MS interface temperature $230^{\circ} \mathrm{C}$, the injection volume was $1 \mu$ l. Helium was employed as carrier gas, at a pressure of 60 $\mathrm{KPa}$; flow rate was $1 \mathrm{ml} / \mathrm{min}$. Mass spectra were detected at $70 \mathrm{eV}$. Temperature programming was set as follows: column temperature was started from $60^{\circ} \mathrm{C}$ (held for $2 \mathrm{~min}$ ) and linearly increased by $5^{\circ} \mathrm{C} / \mathrm{min}$ to $130^{\circ} \mathrm{C}$ (held for $2 \mathrm{~min}$ ); after that it was increased by $4^{\circ} \mathrm{C} / \mathrm{min}$ to $200^{\circ} \mathrm{C}$ (held for $2 \mathrm{~min}$ ); further it was increased by $8^{\circ} \mathrm{C} /$ min. to $250^{\circ} \mathrm{C}$ (held for $10 \mathrm{~min}$ ). Total GC running time was $55 \mathrm{~min}$.

\section{Identification of components}

Interpretation of mass spectra of GC-MS was conducted using the database of National Institute of Standard and Technology (NIST) having more than
62,000 patterns (computer software version 1.10 beta, Shimadzu).

\section{RESULTS AND DISCUSSION}

The GCMS data of $A$. cobbe is represented in Table 1 and plate 1. It indicates that it is the mixture of terpenoids, alkanes and fatty acids. A total of seven compounds were identified with the help of their retention indices as well as by mass spectrometric data. The sample of young leaves of $A$. cobbe comprised of 1,1-diethoxy ethane $(82.97 \%)$, mesostilbene glycol (2.57\%), 1,1-diethoxy propane $(0.6 \%)$, hexanoic acid $(3.67 \%)$, amyl nitrite $(1.13 \%)$, eicosanoic acid, ethyl ester $(2 \%)$ and phytol (7.07\%). Major phytochemicals detected were 1,1-diethoxy ethane (retained by $3.192 \mathrm{~min}$.) and phytol (retained by $43.690 \mathrm{~min}$. from column).

From young leaves of $A$. serratus, 11 compounds have been detected as indicated in Table 2 and chromatogram in plate 2 . It is the mixture of terpenoids and fatty acids. Eleven co mpounds were identified with the help of NIST library and available data. It comprises 3methyl -1-butanol (53.16\%), 2-propenoic acid,2-(dimethylamino) ethyl ester (27.08\%), diisocytyl phthalate $(4.49 \%)$, palmitic acid ethyl aster $(3.51 \%)$, 1,1,3-triethoxy propane (3.17\%), phytol (2.6\%), n-hexadecanoic acid (1.68\%), Nonanoic acid,9-(3-exanylidenecyclo propylidene)-2-hydroxy methyl ethyl ester $(1.17 \%)$, octadecanoic acid, ethyl ester $(1.15 \%)$, 1,1-diethoxy-3-methyl-butane $(1.01 \%)$ and cyclopentyl 2-n-hexadecylcyclopentane $(0.99 \%)$. Major compounds found were 3-methyl 1-butanol (retention time-3.223 min) and propenoic acid, 2-(di methylamino) ethyl ester (retention time-13.942 $\mathrm{min}$ ).

Previous studies by Priya et. al. indicated presence of 22 different compounds in ethanolic extracts of leaves of A. serratus, identified by GC-MS technique, in which cycloheptasiloxane, diethyl phthalate and hexasiloxane were major compounds. ${ }^{13}$ Present study gives different result from that of the study by Priya et. al. which may be due to the difference between type of plant material (in present analysis, only young leaves have been used), the temperature programming and solvent extraction procedure. Various phytochemicals have been isolated from different parts of Allophylus species (See appendix). An anti-ulcer compound phenacetamide have been detected from leaves of $A$. serratus. ${ }^{10}$ Extraction of A. serratus leaves followed by column chromatography over silica gel revealed the presence of various compounds like- pinitol, quercetin, rutin, luteolin-7-O- $\beta$ D-glucopyranoside, and apigenin-4'-O- $\beta$-D-gluco-side which were tested for osteogenic activity. ${ }^{11}$ In vitro 
osteogenic activity was studied using calvarial osteoblasts obtained from Sprague Dawley rats by applying method of Ishizuya et al. ${ }^{11-14}$ Cultured osteoblasts at $\sim 80 \%$ confluence were trypsinised and treated with isolated compounds from plant extracts which indicated increase in alkaline phosphatase activity due to rutin. ${ }^{11}$ Chavan and Gaikwad detected antibacterial activity of aqueous and ethanolic extracts of young and mature leaves of A. cobbe and A. serratus. ${ }^{12} 25 \mu \mathrm{l}(1 \mathrm{mg} / \mathrm{ml})$ each of extract was tested by agar well diffusion method against bacteria-Staphyllococcus aureus and Bacillus subtilis. ${ }^{12}$ As compared to cefotaxime, both aqueous and ethanolic extracts of young and mature leaves of $\mathrm{AC}$ and AS indicated remarkable antibacterial activity against B. subtilis. ${ }^{12}$ A. cobbe exhibited significant nematicidal activity against the root knot nematode Meloidogynae incognita. ${ }^{15}$

There are some reports on phytochemical studies of $A$. cobbe. Screening of leaves and barks of $A$. cobbe gave

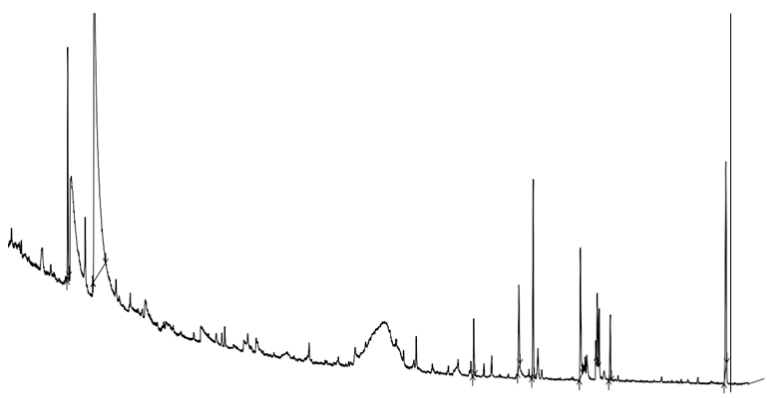

10.0 20.0 30.0 40.0 $50.0 \quad 53.0 \mathrm{~min}$.
Plate 1: Chromatogram of GCMS analysis of young leaves $A$. cobbe
Plate 2: Chromatogram of GCMS analysis of young leaves A. serratus

\begin{tabular}{|c|c|c|c|c|c|c|c|}
\hline C.No. & RT (min.) & $\%$ Conc. & MW & MF & Name & Applications & Ref. \\
\hline 1 & 3.192 & 82.97 & 118.176 & $\mathrm{C}_{6} \mathrm{H}_{14} \mathrm{O}_{2}$ & $\begin{array}{l}\text { 1,1- diethoxy } \\
\text { ethane }\end{array}$ & $\begin{array}{c}\text { flavoring agent in distilled } \\
\text { beverages }\end{array}$ & [29] \\
\hline \multirow{5}{*}{2} & \multirow{5}{*}{43.690} & \multirow[t]{5}{*}{7.07} & \multirow[t]{5}{*}{296.53} & \multirow{5}{*}{$\mathrm{C}_{20} \mathrm{H}_{40} \mathrm{O}$} & \multirow{5}{*}{ phytol } & $\begin{array}{l}\text { Phytol is used in the } \\
\text { fragrance industry and used } \\
\text { in cosmetics, shampoos, } \\
\text { toilet soaps, household } \\
\text { cleaners, and detergents }\end{array}$ & [28] \\
\hline & & & & & & anti-cancer & [24] \\
\hline & & & & & & antimicrobial & [23] \\
\hline & & & & & & anti-radical & [22] \\
\hline & & & & & & anti-inflammatory & [25] \\
\hline 3 & 29.576 & 3.67 & 116.16 & $\mathrm{C}_{6} \mathrm{H}_{12} \mathrm{O}_{2}$ & hexanoic acid & $\begin{array}{l}\text { For manufacture of artificial } \\
\text { flavors, hexyl derivatives }\end{array}$ & [30] \\
\hline 4 & 10.367 & 2.57 & 214 & $\mathrm{C}_{14} \mathrm{H}_{44} \mathrm{O}_{2}$ & $\begin{array}{l}\text { mesostilbene } \\
\text { glycol }\end{array}$ & * & \\
\hline 5 & 40.789 & 2 & 340.5836 & $\mathrm{C}_{22} \mathrm{H}_{44} \mathrm{O}_{2}$ & $\begin{array}{l}\text { eicosanoic acid, } \\
\text { ethyl ester }\end{array}$ & * & \\
\hline \multirow{2}{*}{6} & \multirow{2}{*}{39.864} & \multirow{2}{*}{1.13} & \multirow{2}{*}{117.15} & \multirow{2}{*}{$\mathrm{C}_{5} \mathrm{H}_{11} \mathrm{ONO}$} & \multirow{2}{*}{ amyl nitrite } & $\begin{array}{c}\text { used in heart diseases, } \\
\text { angina }\end{array}$ & [31] \\
\hline & & & & & & $\begin{array}{c}\text { as an antidote in cynide } \\
\text { poisoning }\end{array}$ & {$[32,33]$} \\
\hline 7 & 12.373 & 0.60 & 132 & $\mathrm{C}_{7} \mathrm{H}_{16} \mathrm{O}_{2}$ & $\begin{array}{l}\text { 1,1-diethoxy } \\
\text { propane }\end{array}$ & $\begin{array}{c}\text { used as a reducing agent in } \\
\text { the aerobic epoxidation of } \\
\text { alkenes }\end{array}$ & [34] \\
\hline
\end{tabular}

Abbrv-RT- Retention Time, \%Conc.-percent concentration, MW-Molecular weight, MF- Molecular formula *-literature not found. 
negative tests for alkaloids when tested in the field, but laboratory assays showed the presence of traces of alkaloids. ${ }^{16}$ Large scale extraction of the leaves obtained the crude 'alkaloid' fraction which was found to be an extremely complex mixture of non-alkaloidal material. ${ }^{16}$ Benzylamide has been isolated from leaves of $A$. cobbe. In a phytochemical screening of plants in Crocker range, at Sabah, Malaysia, it was observed that leaves of $A$. cobbe contained saponin while it lacked alkaloids, steroids and triterpenes. ${ }^{17}$ In Vietnam, an anti-diabetic compound, L-quebrachitol has been isolated from the leaves of $A$. cobbe. ${ }^{18}$

In the present study, it is observed that the leaves of both the species are rich in terpenes, alkanes, alcohols, esters and fatty acids. The major compounds found in A. cobbe is 1,1- diethoxy ethane and phytol while the major compound observed in A. serratus is 3-methyl butanol. Two phytochemicals (Hexadecanoic acid, ethyl ester and

\begin{tabular}{|c|c|c|c|c|c|c|c|}
\hline C.No. & $\begin{array}{l}\mathrm{RT} \\
(\mathrm{min})\end{array}$ & $\begin{array}{c}\% \\
\text { Conc. }\end{array}$ & $\begin{array}{c}\text { MW } \\
(\mathrm{g} / \mathrm{mol})\end{array}$ & MF & Name & Applications & Ref. \\
\hline 1 & 3.223 & 53.16 & 88.148 & $\mathrm{C}_{5} \mathrm{H}_{11} \mathrm{OH}$ & 3 methyl-1-butanol & purification of nucleic Acids & [35] \\
\hline 2 & 13.942 & 27.08 & 143 & $\mathrm{C}_{7} \mathrm{H}_{13} \mathrm{NO}_{2}$ & $\begin{array}{c}\text { 2-propenoic acid, } \\
\text { 2-dimethylamino) ethyl } \\
\text { ester }\end{array}$ & $\begin{array}{l}\text { in the manufacture of polymers } \\
\text { and copolymers }\end{array}$ & [36] \\
\hline \multirow{3}{*}{3} & \multirow{3}{*}{52.584} & \multirow{3}{*}{4.49} & \multirow{3}{*}{390.56} & \multirow{3}{*}{$\mathrm{C}_{24} \mathrm{H}_{38} \mathrm{O}_{4}$} & \multirow{3}{*}{ diisocytyl phthalate } & $\begin{array}{l}\text { additive in food packaging } \\
\text { plastic }\end{array}$ & [37] \\
\hline & & & & & & $\begin{array}{l}\text { component of adhesives, } \\
\text { plasticizer of rubbers; used } \\
\text { as a penetration agent for } \\
\text { fungicides; used in teethers } \\
(10.2 \%) \text { and pacifiers }(17.1 \%)\end{array}$ & [38] \\
\hline & & & & & & $\begin{array}{l}\text { used in insulation in building } \\
\text { wire }\end{array}$ & [39] \\
\hline 4 & 40.798 & 3.51 & 284.5 & $\mathrm{C}_{18} \mathrm{H}_{36} \mathrm{O}_{2}$ & palmitic acid ethyl aster & used as lubricant, plasticizer & [40] \\
\hline 5 & 12.350 & 3.17 & 176.2533 & $\mathrm{C}_{9} \mathrm{H}_{20} \mathrm{O}_{3}$ & 1,1,3-triethoxy propane & * & \\
\hline \multirow{3}{*}{6} & \multirow{3}{*}{43.697} & \multirow{3}{*}{2.60} & \multirow{3}{*}{296.53} & \multirow{3}{*}{$\mathrm{C}_{20} \mathrm{H}_{40} \mathrm{O}$} & \multirow{3}{*}{ phytol } & $\begin{array}{l}\text { used in the fragrance industry, } \\
\text { in cosmetics, shampoos, toilet } \\
\text { soaps, household cleaners, } \\
\text { and detergents }\end{array}$ & [28] \\
\hline & & & & & & $\begin{array}{c}\text { phytol has high antimicrobial } \\
\text { activity, high stability, low } \\
\text { toxicity }\end{array}$ & [23] \\
\hline & & & & & & $\begin{array}{l}\text { as cosmetics, hypolipodemic, } \\
\text { anxiolytic and antidepressant }\end{array}$ & [21] \\
\hline \multirow{3}{*}{7} & \multirow{3}{*}{39.931} & \multirow{3}{*}{1.68} & \multirow{3}{*}{256.42} & \multirow{3}{*}{$\mathrm{C}_{16} \mathrm{H}_{32} \mathrm{O}_{2}$} & \multirow{3}{*}{ n-hexadecanoic acid } & $\begin{array}{l}\text { major part of human breast } \\
\text { milk }\end{array}$ & [41] \\
\hline & & & & & & food additive & [42] \\
\hline & & & & & & anti-inflammatory & [43] \\
\hline 8 & 44.725 & 1.17 & 352 & $\mathrm{C}_{21} \mathrm{H}_{36} \mathrm{O}_{4}$ & $\begin{array}{l}\text { nonanoic acid,9-(3- } \\
\text { hexanylidene cyclo } \\
\text { propylidene)-2-hydro xy } \\
\text { methyl ethyl ester }\end{array}$ & * & \\
\hline \multirow[b]{2}{*}{9} & \multirow[b]{2}{*}{45.513} & \multirow[b]{2}{*}{1.15} & \multirow[b]{2}{*}{312.53} & \multirow[b]{2}{*}{$\mathrm{C}_{20} \mathrm{H}_{40} \mathrm{O}_{2}$} & \multirow{2}{*}{$\begin{array}{c}\text { octadecanoic acid, ethyl } \\
\text { ester }\end{array}$} & $\begin{array}{c}\text { used as marker for excessive } \\
\text { alcohol consumption }\end{array}$ & [44] \\
\hline & & & & & & $\begin{array}{c}\text { used in cosmetics, candles, } \\
\text { soaps, plastics, oil pastels, and } \\
\text { for softening rubber }\end{array}$ & [45] \\
\hline \multirow[b]{2}{*}{10} & \multirow[b]{2}{*}{8.316} & \multirow[b]{2}{*}{1.01} & \multirow[b]{2}{*}{160} & \multirow[b]{2}{*}{$\mathrm{C}_{9} \mathrm{H}_{20} \mathrm{O}_{2}$} & \multirow{2}{*}{$\begin{array}{l}\text { 1,1-diethoxy-3-methyl- } \\
\text { butane }\end{array}$} & food flavoring & {$[46]$} \\
\hline & & & & & & $\begin{array}{l}\text { found in beverages and gives } \\
\text { flavor }\end{array}$ & [47] \\
\hline 11 & 37.174 & 0.99 & 362 & $\mathrm{C}_{26} \mathrm{H}_{50}$ & $\begin{array}{c}\text { cyclopentyl } \\
\text { 2-n-hexadecylcyclopentane }\end{array}$ & $\begin{array}{l}\text { compound has been detected } \\
\text { in leaves of highly medicinal } \\
\text { plant Ocimum sactum }\end{array}$ & [20] \\
\hline
\end{tabular}


nonanoic acid, 9-(3-hexanylidenecyclo propylidene)2-hydroxy methyl ethyl ester) from present study have been previously reported from Apricot fruits (Prunus armeniaca L.) detected by GC-MS technique. ${ }^{19}$ Apricot fruit is having therapeutic properties like antioxidant and antibacterial against gram positive bacteria. ${ }^{19}$ Another compound from present investigation-cyclopentyl 2-n-hexadecylcy-clopentane has previously been identified from leaves of highly medicinal plant-Ocimum sanctum..$^{20}$ Phytol is found common in both the species. Phytol is an important phytochemical compound having properties as an anxiolytic, anti-depressant, ${ }^{21}$ anti-radical, ${ }^{22}$ antibacterial, ${ }^{23}$ anti-cancer, ${ }^{24}$ anti-inflammatory. ${ }^{25}$ Thus the abundant presence of phytol in leaves of Allophylus species suggests that these species may prove helpful in prevention of degeneartive diseases. As well as, phytol is used in artificial synthesis of vitamin $\mathrm{E}$ and vitamin $\mathrm{K}^{26,27}$ Additionally, phytol has various applications in cosmetics and fragrance industry ${ }^{28}$ suggests the application of these herbs in cosmetics, which may prove a cost effective alternative to current synthetic chemicals used in current cosmetic industry. Thus, the further detailed studies of each compound will ascertain phytopharmaceutical activity of $A$. cobbe and $A$. serratus. Additionally, to isolate and purify the identified bioactive compounds from Allophylus may be useful to formulate the novel drugs for various diseases.

\section{SUMMARY AND CONCLUSION}

The major compound found in $A$. cobbe was industrially important compound-1,1- diethoxy ethane (flavor imparter in distilled beverages) while the major compound observed in $A$. serratus was 3-methyl butanol (used in flavors and nucleic acid purification). Presence of a very important compound amyl nitrite (used against heart disorders) in $A$. cobbe, opens up new avenues for investigation in cardio protective role of this species. An abundant presence of phytol in leaves of Allophylus species suggests that these species may prove helpful in prevention of degenerative diseases. Phytol is used in

\begin{tabular}{|c|c|c|c|c|}
\hline Species & Name of compound isolated & Source & Biological activity of compound & Reference \\
\hline \multirow[t]{2}{*}{ A. edulis } & Quercetin3- $\beta-D$ glucoside & Branches & Anti-hypertensive & [48] \\
\hline & L-quebrachitol & Twig & Antidiabetic & [49] \\
\hline \multirow[t]{3}{*}{ A. cobbe } & Rutin & Stem & Osteogenic & [11] \\
\hline & L-quebrachitol & Leaves & Antidiabetic & [18] \\
\hline & Benzylamide & Leaves & Nil & [48] \\
\hline \multirow[t]{3}{*}{ A. laevigatus } & 11 acetoxy-4a-methoxy-eudesmane & Fruit & Nil & {$[50]$} \\
\hline & Apigenin 8-c- $\beta$ rhamnopyranoside & Fruit & Nil & [50] \\
\hline & Carissone & Fruit & Nil & [50] \\
\hline \multirow[t]{5}{*}{ A. serratus } & Phenacetamide & Leaves & antiulcer & [10] \\
\hline & $\beta$-Sitosterol & Leaves & antiulcer & [10] \\
\hline & \multirow{3}{*}{ Rutin } & \multirow{3}{*}{ Leaves } & antiosteoporotic & {$[11]$} \\
\hline & & & hepatoprotective & [51] \\
\hline & & & radical scavenger & {$[52]$} \\
\hline & \multirow{3}{*}{ Quercetin } & \multirow{3}{*}{ Leaves } & hepatoprotective & [51] \\
\hline & & & anti-inflammatory, analgesic, aniti-cancer & [53] \\
\hline & & & tyrosinase kinase inhibitor & [54] \\
\hline & \multirow{4}{*}{ Pinitol } & \multirow{4}{*}{ Leaves } & & [11] \\
\hline & & & hepatoprotective & [55] \\
\hline & & & Anti-cancer & [56] \\
\hline & & & Anti-diabetic & [57] \\
\hline & \multirow[b]{2}{*}{ Luteolin-7-O- $\beta$-D-glucopyranoside } & \multirow[b]{2}{*}{ Leaves } & & [11] \\
\hline & & & Inhibits cell apoptosis & [58] \\
\hline & \multirow{2}{*}{ Apigenin-4'-O- $\beta$-D-glucoside } & \multirow{2}{*}{ Leaves } & & [11] \\
\hline & & & against reflux oesophagitis gastritis & [59] \\
\hline
\end{tabular}

(Adapted from: Chavan and Gaikwad, 2016) 
artificial synthesis of vitamin $\mathrm{E}$ and vitamin $\mathrm{K}$. Additionally, phytol has various applications in cosmetics and fragrance industry suggests the application of these herbs in cosmetics, which may prove a natural and cost effective alternative to current synthetic chemicals used in cosmetic industry. Thus, the further detailed studies will ascertain phytopharmaceutical activity of these medicinal species. In addition, the isolation and purification of identified bioactive compounds from Allophylus may be useful to formulate the novel drugs for various diseases. In nutshell, some of the phytochemicals detected in a present study are well known about their bioactivities, fewer are known but little is known about their bioactivities while some are known but there are no reports on their biological activities.

Funding: This research did not receive any specific grant for funding agencies in the public, commercial or not-to-profit sectors.

\section{ACKNOWLEDGEMENT}

Authors are grateful to Mrs. Swati V. Pawar and Mr. Vikas N. Pawar for their suggestions during preparation of manuscript.

\section{CONFLICT OF INTEREST}

The authors declare that they have no conflict of interest.

\section{ABBREVIATIONS USED}

RT: Retention time; min: Minutes; GC-MS: Gas chromatography-mass spectrometry.

\section{REFERENCES}

1. Pant PC. Allophylus. In: Singh NP, Vohra JN, Hajra PK, Singh DK. (eds.). Flora of India 2000;5:345-353.

2. Singh NP, Karthikeyan S. FI. Maharashtra State-Dicotyledons 2000;1:570-571.

3. Yadav SR, Sardesai MM. Allophylus. Flora of Kolhapur District 2002:pp.123-124.

4. Chavan RB, Gaikwad DK. The ethnobotany, phytochemistry and biological properties of Allophylus species used in traditional medicine: a review. World Journal of Pharmacy and Pharmaceutical Sciences 2016;5(11):664-682. DOI:10.20959/wjpps201611-8039.

5. Gaikwad DK. Traditional use of Allophylus cobbe for regenerative fusion of fractured bones and rheumatism. 2004. Abstract in a abstractbook of National Seminar on 'Botany and Industry', held at Deptt. of Botany, Shivaji University, Kolhapur.pp.4.

6. Selvam V. Trees and shrubs of Maldives. Allophylus cobbe (L.) BI. FAO Regional Office for Asia and the Pacific Bangok (publ.), Thailand. 2007. p.21

7. Rastogi RP, Mehrotra BN. Compendium of Indian Medicinal plants CDRI Lucknow and, CSIR, New Delhi vol.1.1990. p. 25.

8. Asia Pacific Medicinal Plant Database downloaded from http://219.93.41.233/ wapi/mctweb/dll/getobject? MID.

9. Dharmani P, Palit G. Exploring Indian medicinal plants for antiulcer activity. Indian Journal of Pharmacology 2006;38(2):95-99. https://doi. org/10.4103/0253-7613.24613.
10. Rastogi RP, Mehrotra BN. Compendium of Medicinal Plants. New Delhi: Publication and Information Directorate; Back to cited text, 3,1995 page.23.

11. KumarM, RawatP, MishraD, GautamAK, PandeyR, SinghD, Chattopadhyay N, Maurya R. Anti-osteoporotic constituents from Indian medicinal plants. Phytomedicine $2010 ; 17(13): 993-999 . \quad$ https://doi.org/10.1016/j.phymed. 2010.03.014; PMid:20554183.

12. Chavan RB, Gaikwad DK. Antibacterial activity of medicinally important two species of Allophylus- Allophylus cobbe (L.)Raeusch. and Allophylus serratus (Roxb.) Kurz. Journal of Pharmacognosy and Phytochemistry 2013;2(1):1-7.

13. Priya ES, Selvan PS, Tamilselvan R. Phytochemical investigation of Allophylus serratus Kurz. leaves by UV and GC-MS analysis. Research Journal of Phytochemistry 2012; DOI:10.3923rjphyto.2012.

14. Ishizuya T, Yokose S, Hori M, Noda T, Suda T, Yoshiki S, Parathyroid hormone exerts disparate effects on osteoblast differentiation depending on exposure time in rat osteoblastic cells. Journal of Clinical Investigation 1997;99:2961-2970. https://doi.org/10.1172/JCl119491; PMid:9185520 PMCid:PMC508148.

15. Jayasinghe ULB, Kumarithamy BMM, Banadara AGD, Waiblinger J. Antifeedant activity of some Srilankan plants. Natural Product Research, 2002;17(1): 5-8. https://doi.org/10.1080/10575630290034285; PMid:12674135.

16. Johns SR, Lamberton JA. Isolation of simple acid amides from Allophylus cobbe (Sapindaceae), Hamalium foetidum (Flacourtceae) and from a Aglabia species (Meliaceae). Australian Journal of Chemistry 1969; 22:1315-1316. https://doi.org/10.1071/CH9691315.

17. Din LB, Yusuoff, NI, Samsuddin MW, Suki U, Salleh KM, Ibrahim AZ, Said LIM. A preliminary phytochemical survey of plants in Crocker Range, Sabah, Malaysia, ASEAN Review of Biodiversity and Environmental Conservation (ARBEC), 2002, p.5.

18. Nguyen TD. Tap Chi duoc lieu, 2006;11:13-14.

19. Sharma S, Satpathy G, Gupta RK. Nutritional, phytochemical, antioxidant and antimicrobial activity of Prunus armenicus. Journal of Pharmacognosy and Phytochemistry 2014;3(3):23-28.

20. Malapermal V. In vitro antidiabetic and antimicrobial properties of Ocimum species (Ocimum basilicum and Ocimum sanctum) (L.) A thesis submitted in fulfilment of the requirements of the degree of Master in Technology at Durban University of Technology, Faculty of Health Sciences, Biomedical Technology and Clinical Technology. Retrived in February 2016. URL: ir.dut. ac.za:8080/bitstream/handle/10321/1534/MALAPERUMAL_2016.pdf

21. Pereira Costa J, da Silva Oliveira J, Mario Rezende Junior L, de Freitas RM. Phytol a natural diterpenoid with pharmacological applications on central nervous system: a review. Recent Pat Biotechnol 2014;8(3):194-205. https:// doi.org/10.2174/187220830803150605162745; PMid:27099143

22. Pejin B, Savic A, Sokovic M, Glamoclija J, Ciric A, Nikolic M, et al. Further in vitro evaluation of antiradical and antimicrobial activities of phytol. Nat Prod Res 2014; 28(6):372-6. https://doi.org/10.1080/14786419.2013.86969 2; PMid:24422895.

23. Mohammad TG, Mohammad HE, Ali J, Seyedhossein H, Mohammad M. Antimicrobial activity, toxicity and stability of phytol as a novel surface disinfectant. Environmental Health Engineering and Management Journal 2015;2(1):13-16.

24. Sheeja L, Lakshmi D, Shruthi Bharadwaj, Parveen K Sajidha. Anticancer activity of phytol purified from Gracilaria edulis against human breast cancer cell line (MCF-7). Int J Curr Sci 2016;19(4):36-46.

25. Renan OS, Francisca BMS, Samara RB, Damasceno NS, Carvalho VGS, Francisco RMA, Oliveira, DPS, Karoline SA, André LR, Barbosa RMF, Jand VRM. Phytol, a diterpene alcohol, inhibits the inflammatory response by reducing cytokine production and oxidative stress. Fundamental \& Clinical Pharmacology 2014;28(4):455-464. DOI: 10.1111/fcp.12049. https://doi. org/10.1111/fcp.12049.

26. Netscher T. synthesis of vitamin E in Litwalk, Gerald. Vitamin $E$ and hormones 2007;76:155-102. doi:10.1016/s0083-729(07)76007-7.

27. Daines A, Payne R, Humphries M, Abell A. The synthesis of naturally occurring vitamin $\mathrm{K}$ and vitamin $\mathrm{K}$ analogues. Current Organic Chemistry 2003;7(16):1625-34. doi:10.2174/1385272033486279. https://doi. org/10.2174/1385272033486279.

28. McGinty D, Letizia CS, Api AM. Fragrance material review on phytol. Food and Chemical Toxicology 2010; 48:S59-S63. doi:10.1016/j.fct.2009.11.012. PMID 20141879. https://doi.org/10.1016/j.fct.2009.11.012. 
29. https://pubchem.ncbi.nIm.nih.gov/compound/Acetal\#section=HumanMetabolite-Information

30. The Merck index: An encyclopedia of chemicals, drugs, and biologicals (11th ed.), Merck, ISBN 091191028X. 1989

31. http://www.mayoclinic.org/drugs-supplements/amyl-nitrite-inhalation-route/ description/drg-20061803.

32. Giannini AJ, Slaby AE, Giannini MC. The handbook of overdose and detoxification emergencies. New Hyde Park, NY. Medical Examination Publishing Co. 1982, pp.48-50.

33. Cheng L, Goodwin CA, Schully MF, Kakkar VV, Claeson G. The effects of nitroglycerin and amyl nitrite on arteriolar and venous tone in the human forearm. Circulation 1965;32(2):755-66. doi:10.1161/01.cir.32.5.755. PMID 4954412. https://doi.org/10.1161/01.CIR.32.5.755.

34. Paul M O'Neill, Stephen indley, Matthew D Pugh, Jill Davies, Patrick G Bray, B Kevin Park, Dauda S Kapu, Stephen A Ward, Paul A Stocks. Co(thd)2:a superior catalyst for aerobic epoxidation and hydroperoxysilylation of unactivated alkenes: application to the synthesis of spiro-1,2,4-trioxanes. Tetrahedron Letters 2003;44(44): 8135-8138 https://doi.org/10.1016/j. tetlet.2003.09.033. DOI: http://dx.doi.org/10.1016/j.tetlet.2003.09.033. https://doi.org/10.1016/j.tetlet.2003.09.033.

35. Green Michael, Sambrook Joseph. Purification of nucleic acids: extraction with phenol-chloroform. Molecular Cloning: A Laboratory Manual. Cold Spring Harbor Laboratory Press. ISBN 1936113422.

36. http://www.chemicalsubstanceschimiques.gc.ca/challenge-defi/summarysommaire/batch-lot-11/140-88-5-eng.php.

37. 21 CFR 175.105 (USFDA); U.S. National Archives and Records Administration's Electronic Code of Federal Regulations. Available from http://www.gpoaccess.gov/ecfr.

38. Stringer R, Labunska I, Santillo D, Johnston P, Siddorn J, Stephenson A. Concentrations of phthalate esters and identification of other additives in PVC children's toys. Environ. Sci. \& Pollut. Res. 2000;7:1-10. https://doi. org/10.1065/espr199910.007; PMid:19153836

39. HSDB (Hazardous Substance Data Bank). Diisooctyl phthalate. National Library of Medicine HSDB Database.

40. http://datasheets.scbt.com/sc-205423.pdf. Santa Cruz Biotechnology database

41. Jensen RG, Hagerty MM, McMahon KE. Lipids of human milk and infant formulas:a review. Am J Clin Nutr 1978;3:990-1016. PMID 352132.

42. US Soil Association standard 50.5.3.

43. Vasudevan A, Kalarickal VD, Pradeep KM, Ponnuraj K, Chittalakkottu S, Madathilkovilaka-thu $\mathrm{H}$. Anti-inflammatory property of $n$-hexadecanoic acid: structural evidence and kinetic assessment. Chemical Biology \& Drug Design 2012;80:434-439. https://doi.org/10.1111/j.1747-0285.2012.01418.x; PMid:22642495

44. Hartwig S, Auwärter V, Pragst F. Fatty acid ethyl esters in scalp, public, axillary, beard and body hair as markers for alcohol misuse. Alcohol \& Alcoholism 2003; 38(2):163-167. https://doi.org/10.1093/alcalc/agg046.

45. http://www.bioquote.com/product.php?id=257372.

46. https://webgate.ec.europa.eu/foods_system/main/?sector=FFL\&auth= SANCAS\&event=substance .view\&identifier $=573$.
47. Francesca M, Giuseppe M, Claudio R, Andrea A. Composition of some commercial grappas (grape marc spirit): the anomalous presence of 1,1-diethoxy-3-methyl butane:a case study. Eur Food Res Technol 2009;228:565-569. DOI 10.1007/s00217-008-0963-2. https://doi. org/10.1007/s00217-008-0963-2.

48. Arisawa, M., Morinaga, Y., Nishi, Y. Ueno, H., Suzuki, S., Hayashi, T., Shimizu, M, Yshizaki, M., Morita, N, Berganza, L.H., Chemical and pharmaceutical studies on medicinal plants in Paraguay constituents of Angiotensin Converting Enzyme inhibitory fraction from Cocu, Allophylus edulis Radlk. Shoyakugaku Zasshi, 1989; 43:78-90.

49. Diaz M, Gonzalez A., Gamboa I.C., Gonzalez D., Rossini C. First record of L-quebrachitol in Allophylus edulis (Sapindaceae). Carbohydrate Research 2008;343:2699-2700. https://doi.org/10.1016/j.carres.2008.07.014; PMid:18715552.

50. David JP, Ihanmarck DS, David JM. A new sesquiterpene from the fruits of Allophylus laevigatus. Fitoterapia 2004;75: 795-798. https://doi.org/10.1016/j. fitote.2004.09.018; PMid:15567269.

51. Tapas AR, Sakarkar DM, Kakde RB. Flavonoids as nutraceuticals: a review. Tropical Journal of Pharmaceutical Research 2008; 7:1089-1099. https://doi. org/10.4314/tjpr.v7i3.14693.

52. Kerry NL, Abbey M. Red wine and fractionated phenolic compounds prepared from red wine inhibit low density lipoprotein oxidation in vitro. Atherosclerosis 1997;135(1):93-102. https://doi.org/10.1016/S0021-9150(97)00156-1.

53. Kumar A, Pandey K. Chemistry and biological activities of flavonoids: an overview. The Scientific World Journal. Volume 2013 (2013), Article ID162750.16 pages.Available from URL:http://dx.doi. org/10.1155/2013/162750. https://doi.org/10.1155/2013/162750.

54. Ferry DR, Smith A, Malkhandi J, Phase I.Clinical trial of the flavonoid quercetin:Pharmaco- kinetics and evidence for in vivo tyrosine kinase inhibition. Clinical Cancer Research 1996;2(4):659-668. PMid:9816216.

55. Sivakumar S, Palsamy P, Subramanian SP. Attenuation of oxidative stress and alteration of hepatic tissue ultrastructure by D-pinitol in streptozotocininduced diabetic rats. Free Radic Res. 2010;44:668-78. https://doi. org/10.3109/10715761003733901; PMid:20370563.

56. Lin TH, Tan TW, Tsai TH, Chen CC, Hsieh TF, Lee SS, et al. D-pinitol inhibits prostate cancer metastasis through inhibition of $\alpha \mathrm{V} \beta 3$ integrin by modulating FAK, c-Src and NF-KB pathways. International journal of molecular sciences 2013 8;14 (5):9790-802..

57. Dang NT, Mukai R, Yoshida KI, Ashida H. D-pinitol and myo-inositol stimulate translocatio $-\mathrm{n}$ of glucose transporter 4 in skeletal muscle of C57BL/6 mice. Bioscience, biotechnology, and biochemistry. 2010;74(5):1062-7. https://doi. org/10.1271/bbb.90963; PMid:20460718.

58. Zhou L, Xie Y, Li J, Wang X, Mou. Protective effects of luteolin-7-O- $\beta-D$ glucopyranoside on hypoxic-ischemic injury of myocardial cells in neonatal rats. Traditional Chinese Drug Research \& Clinical Pharmacology 2008;4:009.

59. Min YS, Yim SH, Bai KL, Choi HJ, Jeong JH, Song HJ, Park SY, Ham I et al. The effects of apigenin-7-O- $\beta$ - $d$-glucuronopyranoside on reflux oesophagitis and gastritis in rat. Autonomic and Autacoid Pharmacology 2005;25(3):85-91. https://doi.org/10.1111/j.1474-8673.2005.00332.x; PMid:15955027.

\section{PICTORIAL ABSTRACT}

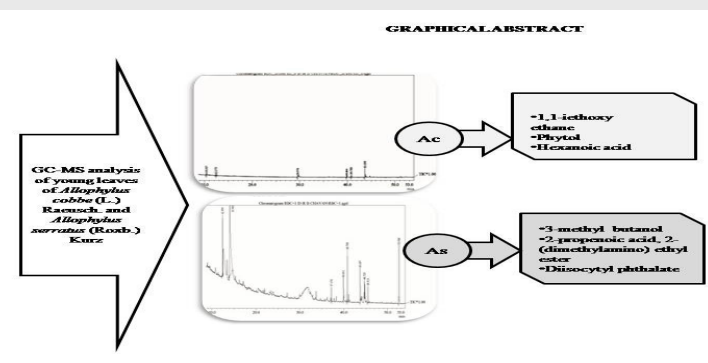

\section{SUMMARY}

- GCMS analysis of young leaves of cobbe and $A$. serratus investigated

- Phytol present abundantly in both species

- Phytol is effective as an anticancer, antibacterial, anti-inflammatory

- Major compound in $A$. cobbe-industrially important compound-1,1- diethoxy ethane (flavor imparter in distilled beverages)

- Major compound in A. serratus-3-methyl butanol (used in flavors and nucleic acid purification). 


\section{About Authors}

Dr. Chavan Reshama Bharat: She has completed her Ph.D. from Dept. of Botany Shivaji University, Kolhapur. Her area of research interest is ethnomedicines, plant physilolgy, plant biochemistry, plant phytochemistry and biomedical technology

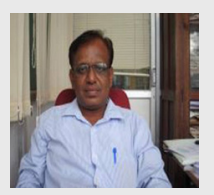

Prof. Dattatraya Krishna Gaikwad: He is the professor and Head of dept of Botany of Shivaji University, Kolhapur. He has guided several PhD and MPhil students. His area of research is plant physiology, plant biochemistry, phytomedicines, plant biotechnology. He has about 28 years of teaching experience in Botany.

Cite this article: Bharat CR, Krishna GD. GC-MS analysis of young leaves of Allophylus cobbe (L.) Raeusch. and Allophylus serratus (Roxb.) Kurz. Indian J of Pharmaceutical Education and Research. 2017;51(3):472-9. 